\title{
IMPLEMENTASI MODEL PEMBELAJARAN PEMAKNAAN DALAM MENINGKATKAN KETERAMPILAN BERPIKIR KREATIF MAHASISWA PGMI STIT MUHAMMADIYAH BOJONEGORO
}

\author{
Miftakhur rizki \\ STIT Muhammadiyah Bojonegoro \\ risqi.dikdas@gmail.com
}

\begin{abstract}
Abstrak
Keterampilan berpikir kreatif menjadi hal yang penting di era abad 21. Keterampilan berpikir kreatif dapat dikembangkan seiring dengan pengembangan potensi pada diri mahasiswa. Mahasiswa merupakan calon guru yang harus memiliki pengetahuan yang mumpuni, sehingga calon guru tersebut kedepannya mampu menciptakan kegiatan pembelajaran yang menarik, bermakna, dan inovatif bagi peserta didiknya. Tujuan penelitian ini adalah untuk meningkatkan keterampilan berpikir kreatif mahasiswa program studi pendidikan guru madrasah ibtidaiyah. Jenis penelitian ini adalah penelitian tindakan kelas yang terdiri dari empat tahapan yaitu; (1) perencanaan, (2) pelaksanaan, (3) pengamatan, dan (4) refleksi. Subjek pada penelitian ini adalah mahasiswa prodi pendidikan guru madrasah ibtidaiyah STIT Muhammadiyah Bojonegoro tahun ajaran 2017/2018 yang berjumlah 12 mahasiswa. Teknik analisis data melalui observasi dan tes. Hasil penelitian ini adalah (1) aktivitas mahasiswa selama kegiatan pembelajaran menunjukkan hasil berkategori baik pada aspek yang diamati; (2) pelaksanaan pembelajaran yang menerapkan model pemaknaan pada kegiatan pembuka, isi, dan penutup adanya peningkatan dari pelaksanaan tiap siklus yang dilakukan; (3) tes keterampilan berpikir kreatif yang dianalisis secara individu dan klasikal menunjukkan hasil rata-rata siklus 1 yakni 45, siklus 2 menjadi 60, dan siklus 3 meningkat menjadi 77.
\end{abstract}

Kata kunci: Model pembelajaran pemaknaan, keterampilan berpikir kreatif

\begin{abstract}
Creative thinking skills are important in the 21st century era. Creative thinking skills can be developed along with the potential of students. Students are prospective teachers who must have qualified knowledge, so that future teachers are able to create interesting, meaningful, and innovative learning activities for their students. The purpose of this study was to improve the creative thinking skills in Islamic elementary schools. This type of research is a classroom action research with four stages; (1) planning, (2) implementation, (3) observation, and (4) reflection. Subjects in this study were students of the teacher education program of Islamic elementary schools in STIT Muhammadiyah Bojonegoro in the academic year 2017/2018 which consisted of 12 students. The technique used for data analysis is through observation and tests. The results of this study are (1) Student activities during learning activities show good results in the aspects observed; (2) implementation of learning that applies the meaning model to the opening, content, and closing activities of an increase in the implementation of each cycle; (3) the test of creative thinking skills analyzed individually and classically shows the average results of cycle 1, namely 45, cycle 2 to 60, and cycle 3 to 77 .
\end{abstract}

Keywords: Meaning learning model, creative thinking skills. 


\section{Pendahuluan}

Pendidikan menjadi salah satu hal yang krusial disaat tantangan peradapan yang semakin maju dan berkembangan. Melalui pendidikan calon generasi bangsa akan mengembangkan segala potensi yang ada pada dirinya dalam kehidupan sehari-hari. Mahasiswa menjadi caloncalon penggerak kemajuan suatu bangsa pada semua aspek bidang baik politik pendidikan, hingga teknologi.

Pendidikan adalah Pendidikan merupakan daya upaya untuk mewujudkan pertumbuhan budi pekerti (kekuatan batin, karakter), pikiran (intellect), dan tumbuh anak (Dewantara, 1977:14). Ketiga bagian itu tidak boleh dipisahkan satu sama lain agar kita dapat memajukan kesempurnaan hidup manusia yang unggul yang mampu bersaing dengan beragam kompetensi sesuai tuntutan perubahan peradapan.

Salah satu yang menjadi tujuan Pendidikan Tinggi adalah berkembangnya potensi Mahasiswa agar menjadi manusia yang beriman dan bertakwa kepada Tuhan Yang Maha Esa dan berakhlak mulia, sehat, berilmu, cakap, kreatif, mandiri, terampil, kompeten, dan berbudaya untuk kepentingan bangsa (undang-undang republik indonesia nomor 12 tahun 2012). Sedangkan menurut Tirtarahardja dan La Sulo (2005:144) pendidikan berkewajiban mempersiapkan generasi baru yang sanggup menghadapai zaman baru yang akan datang. Seperti telah dikemukakan, manusia masa depan harus dihasilkan oleh pendidikan antara lain manusia yang melek teknologi dan dan melek pikiran. Melek pikiran akan melibatkan bagaimana seseorang berpikir dan melatihkan keterampilan-keterampilan berpikir dalam membangun manusia.

Sejalan dengan pendapat tersebut, berdasarkan hasil observasi di STIT Muhammadiyah Bojonegoro menunjukkan masih rendahnya keterampilan berpikir kreatif mahasiswa prodi PGMI. Hal ini dapat dilihat dari tes (pre-test) yang telah diberikan kepada mahasiswa, dengan nilai yang hanya mencapai ketuntasan sebesar 50\%. Selain itu mahasiswa kurang memiliki jawaban untuk alternatif yang lain dalam menyelesaikan soal. Dan mahasiswa cenderung melaksanakan proses kegiatan menjawab soal dengan langsung.

Keterampilan berpikir kreatif perlu dikembangkan terutama dalam menghadapi era infomasi yang semakin berkembang. Kemampuan dalam mengembangkan keterampilan berpikir kreatif yang dimiliki setiap orang bersifat tidak tetap dan akan selalu berkembang. Hal tersebut dipengaruhi oleh perbedaan kemampuan, wawasan serta lingkungan seseorang merupakan beberapa faktor yang berpengaruh terhadap kemampuan berpikir seseorang. Demikian halnya dengan kemampuan berpikir kreatif siswa maupun mahasiswa calon guru dalam pembelajaran dikelas.

Seseorang yang memiliki keterampilan berpikir kreatif akan tumbuh sehat dan mampu menghadapi tantangan (Sumarmo, 2013). Dalam memaksimalkan keterampilan berpikir kreatif mahasiswa, seorang dosen harus mampu menciptakan kondisi dalam kelas yang dapat merangsang penggunaan model pembelajaran yang inovatif. Sehingga para mahasiswa mampu menjadi seorang guru yang professional.

Berdasarkan uraian di atas maka peneliti termotivasi untuk melihat meningkatkan keterampilan berpikir kreatif mahasiswa program studi pendidikan Pendidikan Guru Madrasah Ibtidaiyah melalui model pembelajaran pemaknaan pada mata kuliah perencanaan pembelajaran. Dengan demikian, tujuan dari penelitian ini adalah untuk meningkatkan keterampilan berpikir kreatif mahasiswa program studi pendidikan Pendidikan Guru Madrasah Ibtidaiyah melalui model pembelajaran pemaknaan pada mata kuliah perencanaan pembelajaran. 


\section{Metode Penelitian}

Jenis penelitian ini adalah penelitian tindakan kelas. Penelitian dilakukan terhadap mahasiswa program studi pendidikan Pendidikan Guru Madrasah Ibtidaiyah tahun akademik 2017/2018. Subjek pada penelitian ini adalah mahasiswa program studi pendidikan guru madrasah ibtidaiyah STIT Muhammadiyah Bojonegoro tahun akademik 2017/2018. Pengumpulan data pada penelitian ini, antara lain: (1) Observasi, yaitu merupakan proses penelitian mengamati situasi dan kondisi (Sugiyono, 2008). Observasi yang digunakan dalam penelitian ini berupa pengamatan terhadap aktivitas mahasiswa dan keterlaksaan pembelajaran dengan menggunakan model pemaknaan. (2) Tes, yaitu suatu serentetan pernyataan atau latihan serta alat lain yang digunakan untuk mengukur keterampilan, pengetahuan intelegensi, kemampuan atau bakat yang dimiliki oleh individu atau kelompok (Arikunto, 2010:193). Tes yang dilakukan pada penelitian ini terdiri dari (1) Pre-test, yaitu tes yang dilakukan sebelum perlakuan diberikan untuk mengukur keterampilan berpikir kreatif awal mahasiswa, dan (2) Post-test, yaitu tes yang dilakukan setelah kegiatan pembelajaran yang menggunakan model pemaknaan untuk mengetahui keterampilan berpikir kreatifakhir mahasiswa secara individu dan secara klasikal. Tipe tes yang digunakan dalam penelitian ini adalah tipe uraian dengan tujuan keterampilan berpikir kreatif mahasiswa dapat terlihat jelas dari cara mahasiswa menjawab soal-soal uraian langkah demi langkah, juga dapat menggambarkan seberapa jauh proses berpikir dan kemampuan mahasiswa untuk berpikir kreatif secara baik

Prosedur pada penelitian ini mengacu pada prosedur Suharsimi Arikunto (2012) yang terdiri dari empat tahapan; yaitu perencanaan, pelaksanaan, pengamatan, dan refleksi. Adapun gambar dari prosedur pelaksanaan pada penelitian ini adalah sebagai berikut:

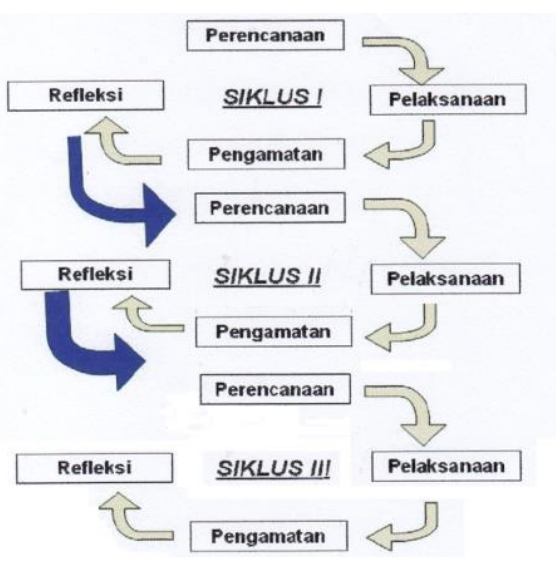

Gambar 1 Prosedur penelitian (Suharsimi Arikunto 2008: 16)

Sedangkan Pemberian skor pada tes keterampilan berpikir kreatif ini didasarkan pada paduan Holistic Creative Thinking Scoring Rubrics (Facione \& Facione, 2007). Holistic Creative Thinking Scoring Rubrics adalah suatu prosedur yang digunakan untuk menskor kemampuan berpikir kreatif mahasiswa. Skor ini diberi level 0, 1, 2, 3, 4, dan 5 . Setiap skor yang diraih mencerminkan kemampuan mahasiswa dalam merespon persoalan yang diberikan dengan mempertimbangkan aspek-aspek keterampilan berpikir kreatif. Kriteria pemberian skor tersebut diadaptasi dari Facione \& Facione (Allen, 2009) yang diuraikan dalam Tabel 1 pada halaman berikut ini 
Tabel 1 Holistic Creative Thinking Scoring Rubrics

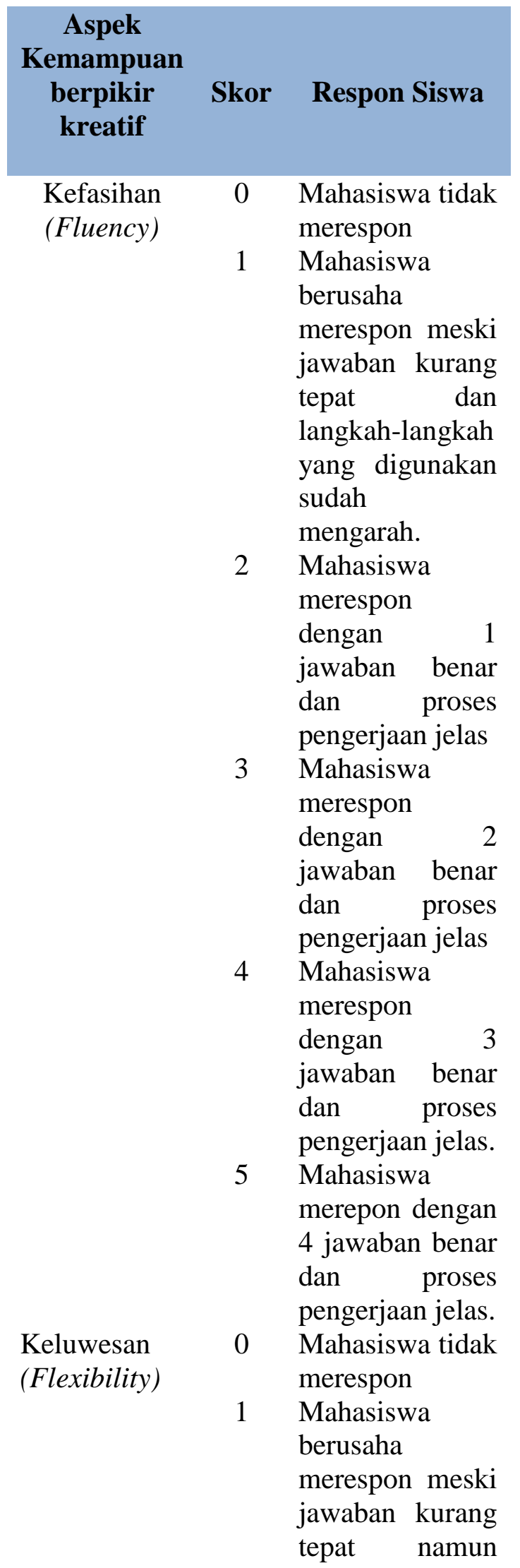

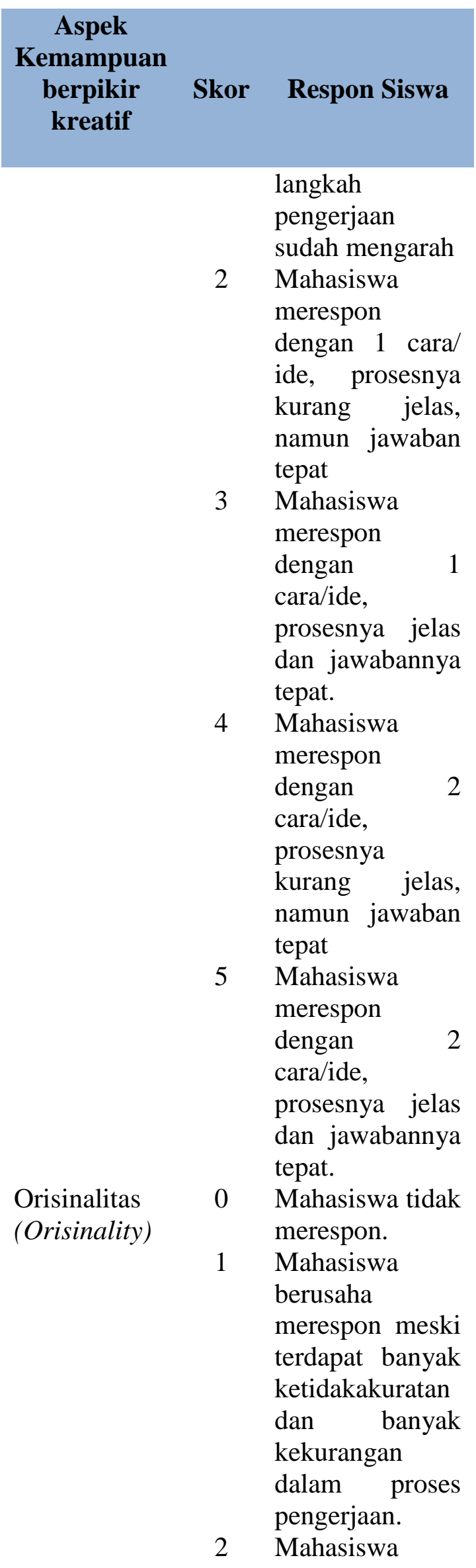




\begin{tabular}{|c|c|c|}
\hline $\begin{array}{c}\text { Aspek } \\
\text { Kemampuan } \\
\text { berpikir } \\
\text { kreatif }\end{array}$ & Skor & Respon Siswa \\
\hline & 4 & $\begin{array}{l}\text { merespon } \\
\text { dengan proses } \\
\text { pengerjaan } \\
\text { yang kurang } \\
\text { tepat namun } \\
\text { jawaban benar. } \\
\text { Mahasiswa } \\
\text { merespon } \\
\text { dengan proses } \\
\text { pengerjaan } \\
\text { yang umum } \\
\text { dilakukan dan } \\
\text { jawaban tepat. } \\
\text { Mahasiswa } \\
\text { merespon } \\
\text { dengan proses } \\
\text { pengerjaan } \\
\text { yang baru dan } \\
\text { unik namun } \\
\text { jawaban kurang } \\
\text { tepat } \\
\text { Mahasiswa } \\
\text { merespon } \\
\text { dengan proses } \\
\text { pengerjaan } \\
\text { yang baru dan } \\
\text { unik dan } \\
\text { jawaban tepat }\end{array}$ \\
\hline
\end{tabular}

\section{Hasil dan Pembahasan}

Berdasarkan hasil analisis data observasi dan tes terhadap mahasiswa STIT Muhammadiyah Bojonegoro program studi Pendidikan Guru Madrasah Ibtidaiyah menunjukkan hasil, sebagai berikut:

\section{a. Hasil Aktivitas Mahasiswa \\ Hasil observasi terhadap aktivitas mahasiswa selama kegiatan pembelajaran yang menerapkan}

model pemaknaan dapat dilihat pada diagram batang dibawah ini.

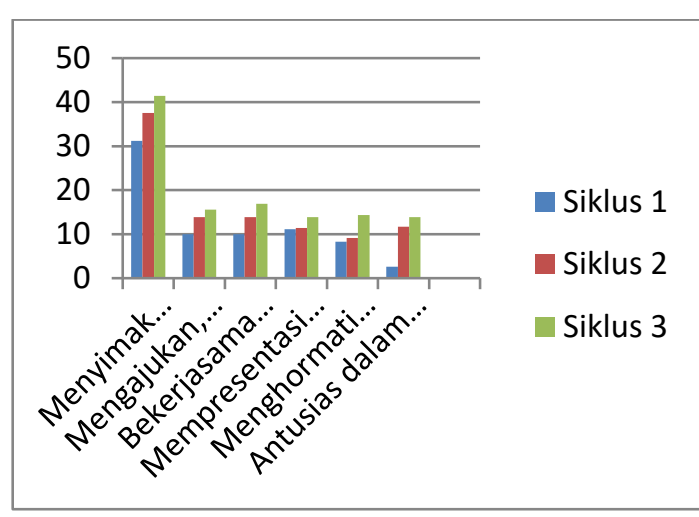

Diagaram 1 Aktivitas Mahasiswa

Berdasarkan persentase dari masing-masing aktivitas mahasiswa yang terdapat pada diagaram batang diatas dapat diketahu bahwa untuk aktivitas mahasiswa pada point (1) Menyimak penjelasan dosen siklus 1 mencapai 31,2, siklus 2 mencapai 37,5 dan pada siklus 3 meningkat menjadi 41,4. (2) Mengajukan, menjawab, dan menanggapi pertanyaan dari dosen siklus 1 mencapai 10, siklus 2 mencapai 13,9 dan pada siklus 3 meningkat menjadi 15,6. (3) Bekerjasama pada saat diskusi siklus 1 mencapai 10, siklus 2 mencapai 13,9 dan pada siklus 3 meningkat menjadi 16,9. (4) Mempresentasikan hasil diskusi siklus 1 mencapai 11,1 , siklus 2 mencapai 11,4 dan pada siklus 3 meningkat menjadi 13,9. (5) Menghormati pendapat orang lain siklus 1 mencapai 8,3 , siklus 2 mencapai 9,1 dan pada siklus 3 meningkat menjadi 14,3. (5) Antusias dalam proses pemaknaan siklus 1 mencapai 2,6, siklus 2 mencapai 11,7 dan pada siklus 3 meningkat menjadi 13,9 . 
b. Hasil pelaksanaan pembelajaran model pemaknaan

Kegiatan obeservasi ini dilakukan selama kegiatan pembelajaran yang menerapkan model pemaknaan dengan melibatkan 2 observer. Hasil observasi terhadap pelaksanaan pembelajaran yang menggunakan model pemaknaan dilihat pada diagram batang dibawah ini.

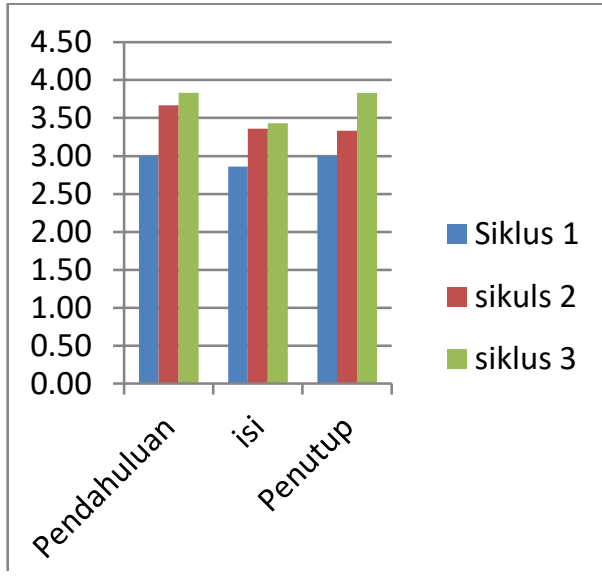

$\begin{array}{lll}\text { Diagaram } & \mathbf{2} & \text { Pelaksanaan } \\ \text { Pembelajaran } & & \end{array}$

Berdasarkan hasil pengamatan terhadap pelaksanaan pembelajaran yang menerapkan model pembelajaran pemaknaan, yang diamati oleh 2 observer dengan memberikan turus pada aspek yang diamati kemudian dirata-rata pada inti kegiatan pembelajaran yakni pendahuluan, isi, dan penutup. Adapun hasil rata-rata pada masingmasing inti yang diamati adalah kegiatan pendahuluan siklus 1 mencapai 3.00, siklus 2 menjadi 3.67, dan pada siklus 3 meningkat menjadi 3.83. Pada kegiatan inti siklus 1 mencapai 2.86 siklus 2 menjadi 3.36, dan pada siklus 3 meningkat menjadi 3.33. Selanjutnya kegiatan penutup siklus 1 mencapai 3.00 , siklus 2 menjadi 3.67, dan pada siklus 3 meningkat menjadi 3.83 .

\section{c. Hasil Ketuntasan Tes keterampilan berpikir kreatif}

\section{1) Hasil Ketuntasa Tes secara Individu}

Hasil tes yang dilakukan untuk menganalisis keterampilan berpikir kreatif siswa secara mandiri, dapat dilihat berdasarkan tabel 2 dibawah ini.

\section{Tabel 2 Hasi Tes Secara} Individu

\begin{tabular}{|c|c|c|c|c|c|c|}
\hline Nama & $\begin{array}{l}\text { Ni } \\
\text { lai }\end{array}$ & Ket. & $\begin{array}{c}\text { Nila } \\
\mathbf{i}\end{array}$ & Ket. & $\begin{array}{c}\text { Nila } \\
\text { i }\end{array}$ & Ket. \\
\hline A1 & 20 & TT & 32 & $\mathrm{TT}$ & 40 & $\mathrm{~T}$ \\
\hline $\mathrm{A} 2$ & 56 & TT & 72 & $\mathrm{~T}$ & 92 & $\mathrm{TT}$ \\
\hline A3 & 80 & $\mathrm{~T}$ & 84 & $\mathrm{~T}$ & 92 & $\mathrm{TT}$ \\
\hline A4 & 32 & TT & 32 & TT & 44 & $\mathrm{~T}$ \\
\hline A5 & 40 & $\mathrm{TT}$ & 60 & TT & 80 & TT \\
\hline A6 & 40 & $\mathrm{TT}$ & 60 & TT & 76 & $\mathrm{TT}$ \\
\hline A7 & 48 & $\mathrm{TT}$ & 60 & TT & 88 & $\mathrm{TT}$ \\
\hline A8 & 56 & $\mathrm{TT}$ & 72 & $\mathrm{~T}$ & 96 & $\mathrm{TT}$ \\
\hline A9 & 36 & $\mathrm{TT}$ & 56 & TT & 76 & $\mathrm{TT}$ \\
\hline A 10 & 48 & $\mathrm{TT}$ & 72 & $\mathrm{~T}$ & 88 & $\mathrm{TT}$ \\
\hline A11 & 56 & $\mathrm{TT}$ & 84 & $\mathrm{~T}$ & 100 & $\mathrm{TT}$ \\
\hline A12 & 32 & TT & 40 & TT & 56 & TT \\
\hline $\begin{array}{l}\text { Rata- } \\
\text { rata }\end{array}$ & \multicolumn{2}{|c|}{45} & \multicolumn{2}{|c|}{60} & \multicolumn{2}{|c|}{77} \\
\hline $\begin{array}{l}\text { Persent } \\
\text { ase } \\
(\%)\end{array}$ & \multicolumn{2}{|c|}{$45 \%$} & \multicolumn{2}{|c|}{$60 \%$} & \multicolumn{2}{|c|}{$77 \%$} \\
\hline
\end{tabular}

Berdasarkan pada tabel 2 diatas dapat diketaui bahwa hasil tes yang dilakukan mahasiswa secara individu menunjukkan adanya peningkatan pada tiap siklus. Diketahui bahwa rata-rata siklus 1 yakni 45 , siklus 2 menjadi 60, dan siklus 3 meningkat menjadi 77 .

Untuk

mengetahui peningkatan masing-masing mahasiswa secara individu maka dianalisis menggunakan n-gain, 
berdasarkan data analisis n-gain menunjukkan hasil sebagai berikut

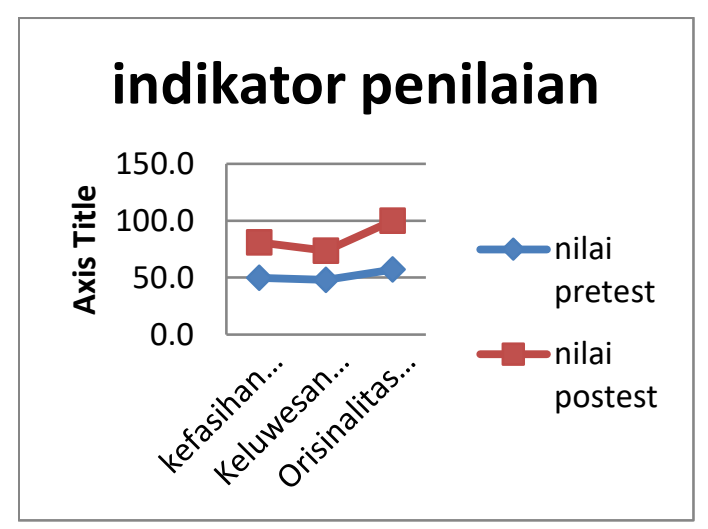

2) Hasil Ketuntasa Tes secara Klasikal

Analisis terhadap hasil tes keterampilan berpikir kreatif mahasiswa dapat dilihat pada diagaram batang dibawah ini.

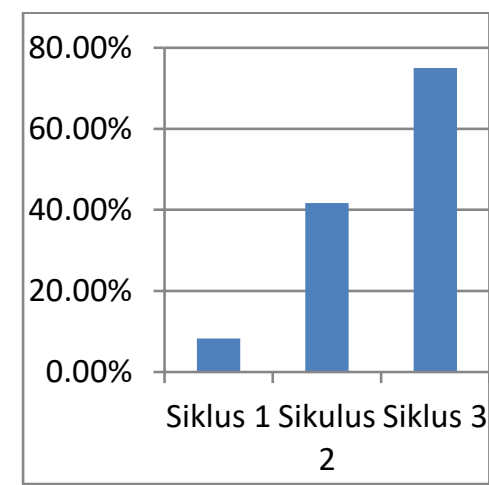

Diagram batang 2 Ketuntasan

Secara Klasikal

Berdasarkan diagaram batang diatas menunjukkan ketuntasan secara klasikal pada siklus 1 mencapai $8,30 \%$, siklus 2 mencapai $41,67 \%$, dan meningkat menjadi $75,00 \%$ pada siklus 3. Berdasarkan pada data tersebut maka peneliti memutuskan untuk tidak melanjutkan pada siklus berikutnya karena capaian pembelajaran secara klasikal sudah berkategori tuntas.

\section{Kesimpulan}

Berdasarkan hasil pembahasan penelitian, maka dapat diambil simpulan sebagai berikut.

a. Aktivitas mahasiswa

Pengamatan terhadap aktivitas para mahasiswa yang menerapkkan model pembelajaran pemaknaan menunjukkan hasil yang meningkat dari siklus 1 , ke siklus 2, dan mencapai target yang diingin kan pada siklus yang ke 3 pada masing-masing aktivitas mahasiswa yang diamati oleh obersever. Akan tetapi pada aktivitas menghormati pendapat orang lain dan antusias dalam proses pemaknaan kurang mencapai harapan yang diinginkan, hal tersebut disebabkan oleh kurang aktifnya para mahasiswa dalam memberikan tanggapan, mahasiswa cenderung menjadi pasif dan menerima apa hasil yang telah dipresentasikan oleh rekan sejawatnya. Selain itu mahasiswa kurang antusias dalam proses pembelajaran yang menerapkan model pemaknaan hal itu disebabkan pelaksanaan pembelajaran yang dilaksakaan pada jam siang mahasiswa sudah merasa letih dan jenuh dalam kegiatan pembelajaran.

b. Keterlaksanaan pembelajaran

Pelaksanaan pembelajaran yang menerapkan model pemaknaan dalam bentuk diskusi kelompok menujukkan hasil yang berkategori baik dari beberap aspek yang diamati oleh observer. Rata-rata pelaksanaan pembelajaran pada kegiatan pembuka, isi, dan penutup menunjukkan adanya 
peningkatan dari pelaksaan tiap siklus yang dilakukan. Akan tetapi pada kegitan inti rata-rata masih belum maksimal tercapai dengan baik. Hal ini disebabkan karena kurang maksimalnya interaksi antara dosen dengan mahasiswa dan kurangnya interaksi yang baik antara para mahasiswa satu dengan yang lainnya.

c. Tes keterampilan berpikir kreatif

Tes keterampilan berpikir kreatif menunjukkan hasil yang baik dalam analsis secara individu ataupun klasikla. Hal ini dapat dilihat dari nilai rata-rata yang sudah mencapai skor 77 dengan katergori lulus. Untuk mahasiswa yang belum lulus perlunya pemberian materi lebih mendalam oleh dosen. Serta memberikan model pembelajaran yang inovatif lainnya guna meningkatkan keterampilan berpikir kreatif mahasiswa dengan optimal.

Dari hasil penelitian ini, peneliti memberikan saran sebagai berikut.

1) Bagi Mahasiswa

Mahasiswa yang sudah mampu dalam konteks berpikir kreatif diharapkan dapat meningkatkan keterampilan berpikir kreatifnya dengan sering berlatih pengajuan pertanyaan-pertanyaan yang inovatif lain agar keterampilan berpikir kreatifnya semakin berkembang.

2) Bagi Dosen

Dosen diharapkan dapat mengembangkan model pembelajaran serta perangkat pembelajaran agar pembelajaraan menjadi lebih inovatif, tidak monoton dan dapat merangsang serta melatihkan keterampilan berpikir kreatif mahasiswa sebagai calon guru madrasah ibtidaiyah.

\section{Daftar pustaka}

Allen, L. V., 2009, Handbook of Pharmaceutical Excipients, Sixth Edition, Rowe R. C., Sheskey, P. J., Queen, M. E., (Editor), Pharmaceutical Press and American Pharmacists Assosiation, London, 697-699.

Arikunto, Suharsimi. 2010. Prosedur Penelitian Suatu Pendekatan Praktik. Jakarta: Rineka Cipta.

Arikunto, Suharsimi. 2012. Prosedur Penelitian.Jakarta: Rineka Cipta

Dewantara, K. H. 1977. Pendidikan. Yogyakarta: Majelis Luhur Persatuan Taman Siswa.

Facione, N.C. \& Facione, P.A. 2007. Holistic Critical Thinking Scoring Rubric. California: California Academic Press.

Sugiyono. 2008. Metode Penelitian Pendidikan Pendekatan Kuantitatif, Kualitatif, dan R\&D. Bandung: Alfabeta.

Sumarmo, Utari. 2010. Berpikir dan Disposisi Matematik: Apa, Mengapa, dan Bagaimana Dikembangkan pada Peserta Didik. Artikel pada FPMIPA UPI Bandung.

Tirtarahardja, Udan La Sulo. 2005. Pengantar Pendidikan. Jakarta: Rineka Cipta.

Undang-Undang R.I nomor 12 tahun 2012. Tentang Perguruan Tinggi. Jakarta. 